\title{
HLA Class II Histocompatibility Antigen, DP(W4) Beta Chain
}

National Cancer Institute

\section{Source}

National Cancer Institute. HLA Class // Histocompatibility Antigen, DP(W4) Beta Chain. NCI Thesaurus. Code C30024.

HLA class II histocompatibility antigen, DP(W4) beta chain (258 aa, $29 \mathrm{kDa}$ ) is encoded by the human HLA-DPB1 gene. This protein plays a role in antigen presentation. 